\title{
Study on Basic Requirements of Geoscientific Area for the Deep Geological Repository of Spent Nuclear Fuel in Korea
}

\author{
사용후핵연료 심지층처분장부지 지질환경 기본요건 검토 \\ Dae-Seok Bae'), Yong-Kwon Koh, Ju-wan Park*, Jin-baek Park* and Jong-soon Song** \\ Korea Atomic Energy Research Institute, 989-111 Daedeok-Daero, Yuseong-Gu, Daejeon \\ *Korea Radioactive Management Company, 89 Bukseong-ro, Kyungju city, Korea \\ **Chosun University, 375 Seoseok-dong Dong-gu, Kwangju city, Korea \\ 배대석1), 고용권, 박주완*, 박진백*, 송종순** \\ 한국원자력연구원, 대전시 유성구 대덕대로 989번길 111 \\ *한국방사성폐기물관리공단, 경상북도 경주시 북성로 89 \\ **조선대학교, 광주시 동구 서석동 375
}

(Received february 21, 2012 / Revised March 23 / Approved March 23)

\begin{abstract}
This paper gives some basic requirements and preferences of various geological environmental conditions for the final deep geological repository of spent nuclear fuel (SNF). This study also indicates how the requirements and preferences are to be considered prior to the selection of sites for a site investigation as well as the final disposal in Korea. The results of the study are based on the knowledge and experience from the IAEA and NEA/OECD as well as the advanced countries in SNF disposal project. This study discusses and suggests preliminary guideline of the disposal requirements including geological, mechanical, thermal, hydrogeological, chemical and transport properties of host rock with long term geological stabilities which influence the functions of a multi-barrier disposal system. To apply and determine whether requirements and preferences for a given parameter are satisfied at different stages during a site selection and suitability assessment of a final disposal site, the quantitative criteria in each area should be formulated with credibility through relevant research and development efforts for the deep geological environment during the site screening and selection processes as well as specific studies such as productions of safety cases and validation studies using a generic underground research laboratory (URL) in Korea.
\end{abstract}

Key words : Spent Nuclear Fuel, deep geological repository, multi-barrier disposal system, requirement, preference, geoscientific suitability indicator

\section{요 약}

사용후핵연료 심지층처분장 부지선정과 최종 처분장부지의 처분적합성을 평가하는 업무는 시행-착오 를 줄이고 기술적 신뢰성 확보와 합리적이고 효율적인 업무수행을 추구하여야 한다. 이에 선행하여, 우리

1) Corresponding Author. E-mail : ndsbae@kaeri.re.kr 
나라에 적용 가능한 처분장부지의 지질환경 요건 설정을 위한 기본방향과 개별 인자의 처분적합성지표를 가능한 한 정량화하여 설정하고 업무에 적용하여야 한다. 사용후핵연료 처분장부지 선정과 최종처분장 부지의 안전성확보를 위한 처분요건과 관련하여 IAEA 및 OECD 회원국들과 처분연구 및 상용사업 수행 관련 선진국가들의 사례를 바탕으로 요건 별로 구분하여 현황을 분석하였다. 여기서는 사용후핵연료 처 분장 부지로서 암석 · 암반이 갖추어야 할 충분 혹은 선호요건에 대한 이해 제고와 관련 세부 기술지침을 도출하는데 기여하고자 하였다. 이를 토대로 어떠한 암석 · 암반이 상대적으로 보다 유리한 조건을 가지 는 선호요건으로 제시해야 하는지, 그리고 충분요건과 선호요건을 적용하여 후보부지 조사 · 선별평가 기 간 동안 부지선정업무에 반영하고 평가하고 결정하여야 하는 방법론을 도출할 수 있도록 기본 골격을 제 시하였다. 또한 처분안전성 확보를 위해 필요한 기본적인 사항을 검토하고 서술하였다. 본 논문에서 기술 한 항목들은 처분안전성 확보를 위한 처분요건의 기술지침 구성 체계, 처분안전성 확보개념, 다중방벽 기 능 조건, 천연방벽의 지질환경 기본요건, 그리고 우리나라에 적용 가능한 처분장부지 지질환경 기본요건 (안) 등으로 구성된다. 우리나라의 사용후핵연료 심지층처분장 부지의 위치에 관한 사업자 기술지침 요건 으로 제안하였다. 이와 관련하여 충분요건과 선호요건으로, 화산활동, 지진활동, 단층운동 융기 - 침강 운 동 및 기후 · 해수면변동 등 장기지질안정성 요건을 비롯한 15 개 충분요건과 48 개 선호요건을 제안하였 다. 이들 요건은 우리나라의 지질환경 특성을 충분히 반영하여 후속되는 각 부문별 특성에 적합한 정량적 인 기술 기준 및 지침으로 개발되어야 할 것이다. 정량적 기술지침의 도출은 상용 처분장부지 선별평가과 정 및 처분장 부지적합성평가 과정으로부터 확립될 수 있을 것이다. 또한 다양한 부문별 안전사례(safety case) 작성 혹은 연구용 지하처분연구시설 (underground research laboratory: URL)을 이용한 처분시스 템의 실증과정 등을 통하여 객관적이고 신뢰성있는 정량적인 지침들이 확립될 수 있을 것이다.

중심단어 : 사용후핵연료, 심지층처분장, 다중방벽시스템, 충분요건, 선호요건, 처분적합성지표

\section{I. 서 론}

발열폐기물을 포함한 사용후핵연료 재처리과정에서 발생한 고준위방사성폐기물(이하, 고준위폐기물)의 심지층처분은 지 하 갱도 혹은 공학적시설, 기존 광산, 및 심부 시추공 처분 등 의 처분방법들을 통칭하는 의미로서, 일정기간 동안 지표 혹 은 지하 천부의 처분시설에서 이들의 능동적관리가 가능하다. 우리나라는 한국방사성폐기물관리공단(KRMC)의 발족과 함께 중저준위처분시설의 안전심사 및 건설허가 등, 방사성 폐기물관리에 관한 새로운 국면에 진입하였다[1]. 하지만 아 직까지 사용후핵연료관리에 관한 장기관리정책은 결정된 바 는 없으며 현재 사회적 의견수렴을 거쳐 국민적 합의점을 찾 아 가는 과정에 있다. 한편 "고준위방사성폐기물심층처분시 설에관한일반기준고시(안)" (이하, 일반기준고시(안))[2]에 대 하여 의견수렴 과정 중에 있어, 사용후핵연료의 관리차원에 서 처분에 관한 논의와 준비업무도 시작되었음을 시사한다. 이와 함께, 하위 규제관련 기준 및 세부 기술지침들이 후속적 으로 제정-고시될 것이다. 상용사업 추진 분야에서는 세부 적이고 구체적인 종합수행계획의 수립 및 세부일정 등과 함
께 사업수행에서 제일 먼저 대두되는 처분장부지 선정을 위 한 후보부지 선정평가 업무와 자국 고유의 처분시스템 실증 업무 및 부지특성평가 등이 전개될 것이다. 즉 사업자 기준의 처분환경에 대한 자국 고유의 지질환경 특성을 반영한 처분 적합성지표(site suitability indicator)를 정량화 - 정의하는 과 정은 반드시 거쳐야 할 명제이다. 특히 심지층처분장의 지질 환경 요건은 다양하고 복잡한 물리-화학-생물학적 연계 현상 의 시 · 공간적인 변화 특성을 반영할 수 있는 가능한 한 정량 적인 내용을 요구하고 있다. 기술적 측면에서 사용후핵연료 심지층처분장 부지로서 갖추어야 할 국제적으로 권고하는 수 준의 처분요건과 이를 토대로 한 국내 제반 여건을 감안한 관 련 기술기준들이 요구될 것이다.

본 논문에서는 심지층처분장의 지질환경 요건에 대하여 광 역-세부 등의 방향 설정을 위한 고려 사항들에 대하여 논의하 였다. 먼저 국제적인 배경의 근원을 간략하게 기술하고, 향후 정량적인 충분 혹은 선호요건(requirement, preference)의 정의를 위해서, 출현 배경과 이에 대한 이해 제고 및 관련 세 부 기술지침을 도출하는 기반구축을 위하여 수행하였다. 이 를 토대로 정성적인 수준의 예상 기술지침(안)을 제시하였다. 
Study on Basic Requirements of Geoscientific Area for the Deep Geological Repository of ...

충분요건과 선호요건을 적용하여 후보부지 조사 - 선별평가 기간 동안 부지선정 업무에 반영하고 평가하고 결정하는 방 법론 도출을 위한 기본 골격을 제시하였다.

\section{II. 처분장부지 지질환경요건의 국외 및 국내 환경}

사용후핵연료의 최종 처분과 관련한 관리 방법은 원자력과 방사성물질을 이용하는 우리 세대가 해결하여야 하는 현안과 제이다. 폐기물의 잠재적인 위해성으로부터 인류보건과 환경 의 보호는 수용 가능한 수준으로 최대한 저감시킬 수 있도록 관리되어야 한다. 이와 같이 방사성폐기물관리에 적용되는 안전기본원칙(safety fundamentals)은 IAEA SS No-111F를 통해서 확립되었다[3].

ICRP는 최종처분을 위한 최적 방사능방호 기준에 대하여 선량 - 위험도 (dose - risk) 목표치를 제안하였고[4], ICRP 81 에서 처분의 장기안전성 확보를 위한 평가기준치로서 선량 위험도 목표치를 $0.3 \mathrm{~m} \mathrm{~Sv} / \mathrm{yr}$ 및 $10^{-5} / \mathrm{yr}$ 으로 정의한 바 있다 [5]. 선량 - 위험도 목표치는 성능기간 시간 범위로 1,000 년 10,000 년 동안에 해당하는 값에 대한 정량적인 수준으로 간 주한다. 최종처분에 대한 ICRP 103의 권고치는 향후 선량 목 표치에 대하여 보호 및 저감을 목표로 반복수행 방법에 의해 방호에 관한 최적화를 제시하였다[6].

IAEA safety standard program의 안전표준은 안전기본원 칙, 안전기본요건(safety requirements) 및 안전기술지침 (safety guides)으로 구성된다. 방사성폐기물 처분안전성과 관련한 제규정의 체계 구축을 위한 최초 안전표준 관련 지침 으로서 후세대에 대한 부담 해소와 제도적 관리에 대한 독립 적인 접근방안에 대하여 정의하였다 $[7,8]$. 최종처분을 위한 선량 - 위험도 상한치로서 기본적인 안전기준을 제시하였다. 후세대를 위한 당해 세대의 책임은 안전기본원칙과 함께, 세 부 사안으로 후세대 보호, 후세대에 책임부담 전가 지양, 세 대간 평등, 그리고 인간 및 자연환경의 보전 등과 함께 정 부 · 규제기관이 기술적 및 관리측면의 권한 등을 확실하게 정의하도록 강조하였다[9]. 또한 국제적 및 국가적 차원의 안 전보호 목표 수준과 "안전사례(safety case)" 등, 장기적 안전 성입증, 적정 처분장 부지확보(siting) 및 설계, 적정 수준의 신뢰성을 갖는 단계적 정책결정, 효율적인 관리체계, 다중 안 전성기능의 적용 등에 대하여 권고하였다.

IAEA는 ICRP의 권고에 따라, 국제적으로 수용하는 방사능 안전표준은 방사능으로부터 보호 및 방사성 선원의 안전관리 등을 위해 국제적 기본안전표준(basic safety standards)" 의 확 립과 함께, 국제적으로 수용하는 방사선 안전표준은 이온화방
사선에 대한 보호 및 방사선 선원의 안전관리 등을 위해 국제 적 기본안전표준을 확립하였다[10]. 한편 IAEA는 안전기본원 칙의 9개 세부원칙을 토대로 방사성폐기물의 처분안전성 확 보를 위한 기본요건으로 26개 요건을 수립 및 제시하였다[11].

NEA-OECD의 방사성폐기물관리위원회 (Radioactive Waste Management Committee: RWMC)는 실무그룹으로 하 여금 방사성폐기물의 최종처분에 관한 요구조건을 도출하였 다. 여기에는 규제자, 정책입안자, 사업자, 및 연구기술개발 등의 분야의 담당자뿐만 아니라 광범위한 분야의 이해당사자 들이 대화에 참여토록 하였다. 처분장의 안전성입증 방안으 로 안전사례의 중요성을 강조하였다[11, 12, 13]. NEA의 다양 한 실무그룹과 위원회에서 노출선량과 위험도 보다 처분 안 전성 - 성능을 나타내는 인자 · 지시자가 처분시스템의 설계 를 위한 기본 정보 제공과 함께 상이한 성능기간 시간범위 체 계에 적용되고 사용되어야 한다는 결론에 도달하였다[14]. 장 기적 안전성에 대한 규제측면의 요구조건은 NEA 실무회의에 서, 장기적 성능기간 범위의 한계성과 지질환경 관련한 과학 기술적 측면과 인문 - 사회문화적 측면에 근거한 상이한 성능 기간 개념의 존재 등에 대하여 논의되었다[15]. 또한 정성적 인 평가와 신뢰도 강화에 대하여 자연유사(natural analogue) 뿐만 아니라 안전성평가 결과와 이 결과에 대한 신뢰성 등을 포함하는 논쟁의 선택 - 결정 등 안전사례에 대하여 구체화하 여 정의하였다[16].

ICRP 권고, IAEA의 안전표준 그리고 NEA 등 수많은 질의 와 토의, 실무자 회의, 그리고 주요 현안에 대한 검토과정을 거쳐 최종적으로 국제적 및 국가적 차원의 공감대를 토대로 하는 접근방안이 확립되었다. 이러한 국제적 수준의 처분안 전성과 관련한 기본적인 생각들을 토대로 자국의 제반 환경 여건을 반영한 처분안전성 확보 규제 기준들을 개발 및 적용 할 수 있는 근간으로 작용하게 되었다.

국내의 경우 고준위폐기물처분장 부지선정 요건과 관련한 연구는 고준위폐기물처분 관련 중장기연구가 시작되면서 일 부 처분환경 요건에 관한 검토가 있었다[17]. 한편 지식경제 부의 정책연구 일환으로 한국원자력연구원이 수행한 부지선 정 기준 및 절차수립에 관한 연구 등을 수행한 바 있다[18]. 또한 규제기관에 의해 "일반기준고시(안)" [2]이 의견 수렴 중 에 있는 상황이다.

\section{III. 국내 처분안전성 규제 요건 접근}

\section{가. 성능기간의 시간 범위}

성능기간은 사용후핵연료의 처분안전성 확보를 위해 요 
구되는 처분시스템의 성능 유지기간을 나타내는 시간 범위 로서, 안전성평가 시 요구되는 최소한의 평가기준으로서 시 간적 범위(cut-off time)를 말한다. 처분사업 선행 국가들을 중심으로 수많은 규정과 안전사례는 백 만년에 달하는 범위 의 평가기준 기간을 성능기간으로 제안하고 있다. 미국의 경우, $\mathrm{EPA}$ 에서 10,000년으로 규정한 평가기준 기간에 대한 법원의 이의 제기에 따라[19], EPA는 유카산처분장 안전성 평가를 위해 성능기간 시간 범위를 $1,000,000$ 년으로 적용하 는 것이 타당하다는 NAS(National Academy of Science) 권 고를 수용하여 규정을 재검토 수정한 바 있다[20]. 한편 스웨 덴의 경우 처분장 폐쇄후 1,000년, 100,000년 그리고 100,000 년 이상 등, 세 가지로 분류하여 적용하였으며, 프랑 스는 10,000 년까지 성능기간을 적용하여 평가하도록 규정 하고 있다[21].

장기안전성 기준에 관한 가장 윤리적인 측면에서, 한 세 대는 그 후세대를 위한 대안을 이해하고 폐기물로 인한 위 험도의 영향이 존재하는 한 성능기간의 범위 제한은 없다는 것이다. 불확실성은 성능기간 범위가 길어질수록 증가한다 는 사실과 이러한 증가현상은 성분 - 요소에 따라서 변할 수 있으며, 규정과 안전사례 등의 다양한 방법으로 제기 및 접 근한다.

\section{나. 인간보호를 위한 선량 - 위험도 기준}

선량과 위험도 중, 위험도는 보다 더 근본적인 개념으로 서 선량치에 비해서 기준으로서 적용이 보다 더 적합하다. 하지만 위험도 개념은 이해하기 어렵고 먼 장래의 특정 사 건에 대한 적용 시 큰 불확실성의 노출 가능성 등 난관이 많 아서, 진화시나리오와 가장 흡사한 경우에 대하여 주요 지 표 혹은 기준으로서 선량치를 사용할 것을 권고하였다. 한 편 위험도에 대한 확률-결과 형태로 분석되어야 하는 불확 실성 시나리오에 대하여 위험도를 고려할 것을 권고하게 되 었다.

NEA 회원국들이 사용하는 규제기준들의 노출선량, 위험 도, 노출선량-위험도 병용, 그리고 기타 기준 값의 범위 등 기준의 다양성이 확인된다[11]. 미국의 경우 peak dose로 $0.15 \mathrm{~m} \mathrm{~Sv} / \mathrm{y}(10,000$ 년 이내 $)$ 와 $1 \mathrm{mSv} / \mathrm{y}(1,000,000$ 년 이내 $)$ 로 이원화하여 적용하였다. 핀란드는 일반인에 대한 선량한도 를 $0.1 \mathrm{mSv} / \mathrm{y}$ 를 제시하면서 확률자연현상(event) 및 인간침 입으로 인해 야기되는 상한치를 $5 \mathrm{mSv} / \mathrm{y}$ 를 제시하였으며, 프랑스는 $0.25 \mathrm{mSv} / \mathrm{y}$ 로 제시하였다. 한편 스웨덴은 선량개 념이 아닌 위험도를 적용하여 $10^{-6} / \mathrm{y}$ 수준 이하로 제한하고 있다[21].
우리나라는 현재 논의 중인 "일반기준고시(안)" 에서 폐쇄 후 방사선영향에 대한 안전목표치 기준으로서, 다양한 잠재 위해를 효과적으로 통합하기 위해 전체시스템 안전지표로 위험도를 적용하도록 하였다[2]. 위험도 제약치를 중 - 저준 위방사성폐기물 처분에 대해 고려되는 목표 $\left(10^{-5} / \mathrm{y}\right)$ 보다 강 화한 수준 $\left(10^{-6} / \mathrm{y}\right)$ 으로 설정 - 제안하였다. 보조적으로, 결정 론적 접근에서, 개별 피폭시나리오의 결과를 제한하기 위해 확률자연현상과 인간침입 등 미래의 상황에 대해 개입이 정 당화될 수 있는 선량범위의 하한 수준 $(10 \mathrm{mSv} / \mathrm{y})$ 으로 시나 리오 당 선량제약치를 적용하도록 하였다.

진화하는 안전사례 개념과 잘 일치하도록 기준치를 만족 하는 수준 이상의 현안문제에 대한 규제기준들은 증가하고 있다[10,12, 22]. 완벽한 부지확보, 설계, 설비관련 기술, 최 적화 현안, 수용 가능한 최고기술, 그리고 적절한 관리 기본 원칙 - 시행 등 다양한 업무 내용과 현안에 따라서 만족도 평가의 특정 항목에 대한 상대적인 중요성이 강조되어야 한 다. 근래 국가차원의 규제 규정 및 지침에 있어서 "복합적 요소(multiple factors)" 혹은 "복합적 유형의 증거 제시 (multiple lines of evidence)" 에 대한 요구가 설득력을 얻게 되었다.

\section{IV. 처분시스템 구축}

전술한 국제적 환경과 이를 바탕으로 하는 자국의 규제 요 건들은 상용 처분사업 수행을 위한 심지층처분시스템을 구축 하는 기초가 된다. 심지층처분은 방사성폐기물관리의 목적을 달성하기 위해 선호되는 방법으로 처분대상 폐기물을 생태계 로부터 격리시켜 집중 관리하는 방법이다.

\section{가. 심지층처분 개요}

심지층처분시스템의 격리기능의 확보 방법은 폐기물 자체 의 격납용기, 포장재, 완충재 및 뒷채움재와 처분장 주변 모암 등으로 구성된다. 처분심도와 처분장 모암의 지질환경 특성은 높은 수준의 집중도와 장주기성 고체폐기물에 대한 높은 수준 의 격납기능과 필요한 수준의 격리기능을 제공한다. 처분시스 템 안전성은 다중방벽의 안전성기능(safety function)에 대한 장기안전성 확보는 관련 업무들이 유연성 있게 상호 연계되어 지원됨으로써, 처분개념, 부지확보, 설계, 건설 - 운영 관리 및 폐쇄 등과 같은 중요한 정책 결정은 수용 가능한 정보와 신뢰 성을 토대로 일련의 단계 별 수행 업무의 일환으로 이루어진 다. 처분시설 폐쇄후 안전성은 공학적방벽과 천연방벽의 기능 에 의존함으로써, 폐쇄 후 제도적 감시 관리에 의존하지 않는 
수동적 관리(passive control)개념이다. 하지만, 감시관리 행 위가 필요 없다는 의미가 아니라 폐쇄 후 일정기간 동안 사회 적인 수용성과 방사선방호 목적 등 특별한 경우에 따라 유연 하게 적용한다.

심지층처분의 일차적인 설계 목표는 처분시설 폐쇄 후 장기 간 동안 인간 및 환경의 보호기간 동안 다중방벽의 풍화 혹은 손괴와 자연환경의 진화현상(FEP: feature/정적자연현상; event/확률자연현상; process/정상자연현상)으로 인하여 방 사성핵종이 생태계로 이동 및 이로 인한 인체에 노출의 저지 이다. $\mathrm{FEP}$ 로 인한 방사선에 노출될 수도 있는 불확실성 환경 하에서, 안전성입증은 이러한 제반 사건들의 발생 확률과 잠 재적인 노출규모 모두를 고려함으로써 수행된다.

심지층처분시스템의 안전성확보 요건으로 기본요건, 환경 요건, 안전성요건 및 방호요건 등으로 구분된다. 또한 폐쇄후 제도적 감시관리 없이 안전성에 필수적인 각 방벽의 기능이 유지되어야 한다. 처분장부지 및 광역적 체계에 대한 전반적 인 이해는 처분시스템에 대한 설득력 있는 과학적 - 기술적 정 의를 확립하여야 하고, 안전성평가에 적용한 체계적이고 기본 적인 특성으로 인정될 수 있다. 안전성평가는 처분시설에 의 해 수반되는 방사선적 위험성에 대한 체계적인 분석을 이행하 는 과정이며, 또한 성능에 관한 전반적인 수준의 정량화, 관련 불확실성의 분석 및 설계 요건과 안전표준의 비교분석 등을 포함한다. 또한 평가 결과에 영향을 미칠 수도 있는 자료 혹은 분석과 같은 과학적인 이해에 있어서 중대한 결함에 대한 규 명도 포함한다. 예기치 못한 진화와 사건에 대하여 예상되는 처분시스템의 성능을 분석하여야 하고, 민감도 및 불확실성 분석은 진화 및 사건의 범위 하에서 처분시스템의 성능과, 성 분을 이해하도록 지원, 수행되어야 한다.

안전사례의 개발 및 안전성평가 지원 업무는 심지층처분시 설 개발의 핵심 사안으로서 처분시설의 안전성확보와 관련된 모든 과정, 절차, 방법 및 결과에 관한 신뢰수준을 서술하고, 정량화하여 입증하는 모든 토의/논거 및 증거들의 수집 업무 이다[12](Figure. 1). 그리고 처분시스템의 예상 진화현상과 시 스템의 성능에 영향을 미칠 수도 있는 사건의 범위를 제시하 여야 한다. 또한 자국의 지질환경에 적합한 처분적합성지표 확립 및 처분시스템 개발과 함께, 처분관련 연구 및 기술개발, 부지확보, 설계 및 건설·운영 업무에 대한 기술지침을 위해 사용되어야 한다.

\section{나. 지질환경의 기능과 영향}

심지층처분장의 안전성확보에 영향을 미치는 요소들은 가 장 우선적으로 정의되어야 하는 현안과제이다. 심지층처분장

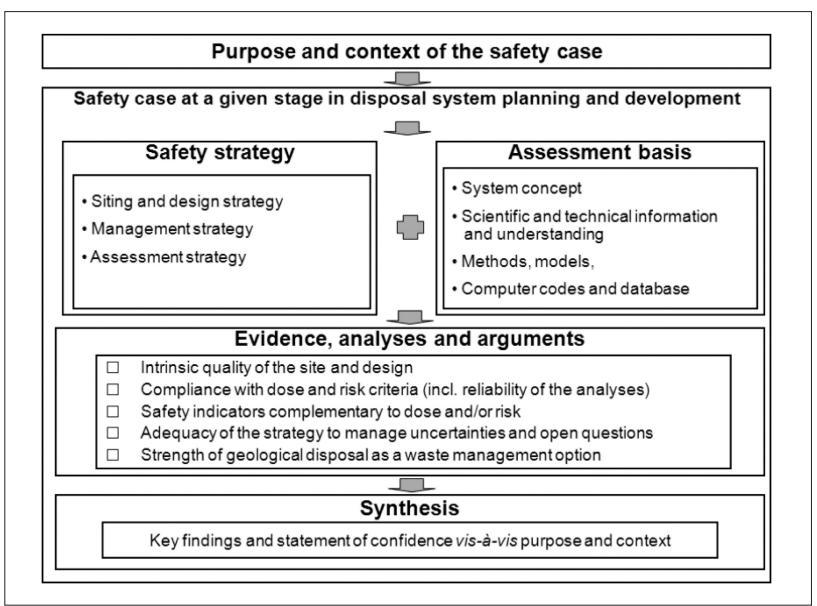

Fig. 1. An overview of the relationship between the different elements for a safety case[12]

의 다중방벽개념에 의한 안전성확보를 위한 기본원칙은, 우선 적으로 인간 및 자연환경으로부터 폐기물의 격리기능과, 핵종 이 처분장으로부터 누출되었을 경우 생태계에 이르는 환경에 서 충분한 지연기능 등을 확보하는 것이다.

격리기능은 심지층처분장의 일차적인 기능인, 인간 및 환경 으로부터 방사성폐기물을 격리시킴으로서 내부식성 재질의 캐니스터에 의해 직접적으로 확보된다. 완충재는 부식물질이 캐니스터와 접촉하는 현상을 방지하는 보조 역할을 하고, 암 반은 캐니스터와 완충재에 대하여 역학적, 화학적 안정조건을 제공함으로써 격리기능을 지원하는 역할을 한다. 지화학적 조 건 중, 일차적인 지하수 조성은 구리와 같은 재질과 완충재에 해로운 영향을 미치는 용존 물질의 농도가 낮을 경우 보다 유 리하다. 또한 지하수유동이 매우 느려서 처분장 내부로 위해 성 물질의 유입 규모가 제한될 경우 매우 유리한 환경조건이 된다. 역학적으로는, 처분동굴 및 처분공의 외형 유지 및 단열 생성으로 전술한 물질들의 이동이 용이하지 않는 응력조건 상 태가 바람직하다.

지연기능은 만약 격리기능이 어떠한 이유로 수정 - 보완되 어야 한다거나, 캐니스터 설치 후에 근본적인 결함을 발견하 지 못할 수도 있다. 이러한 상황에서 심지층처분장은 2 차적인 지연기능으로서, 핵종이 이동되어 인간 혹은 지표생태계에 도 달하기 이전에 방사성독성이 무해한 수준으로 저감될 수 있는 충분한 시간이 보장되도록 하는 기능의 지질환경 특성이다. 처분장의 실제 설계 이외에, 지하수의 화학성분, 암반 내에서 지하수유동 및 핵종이동 특성 등은 처분장의 지연기능에 영향 을 미치는 요소이다.

희석 및 분산 기능은 제 3 의 안전성확보 기능으로 작용한다. 즉, 핵종이 누출되면 생태계에서 상당한 규모의 희석현상으로 
그 독성이 완화된다. 하지만 이러한 효과는 현재까지 안전성 기능으로 적극적으로 반영하지는 않고 있다[22]. 그 이유는 생 태계에서 희석현상은 처분시스템의 진화보다 훨씬 빠른 속도 로 변화함으로써 이를 예측하는데 상당한 어려움이 있다. 또 한 생태계의 임의의 환경 하에서 장기적 안전성을 평가하는 자체가 비합리적이고, 핵종누출에 의해 가장 영향을 많이 받 는 현상이 완화되더라도, 특정 핵종은 오히려 집중적인 영향 을 받을 수도 있다는 점이다. 그럼에도 불구하고 희석현상은 생태계에서 누출 핵종의 영향 완화에 상당한 영향을 미치는 중요한 요소임은 분명하다.

\section{V. 처분장부지 지질환경 요건 구성 체계}

\section{가. 처분 관련 법적 근거 및 현황}

우리나라는 환경보호기본법과 원자력법 및 관련 시행령?규 칙 등이 있으며, 이외 관련성이 있는 제반 법규들을 반영한 방 사성폐기물관리법(2009)이 제정 · 공포되어 있다.

심지층처분장의 성능은 전술한 방사선적 선량제한치를 만족 하는 수준의 기능을 가지는 방벽조건을 지원할 수 있는 지질환 경 요건을 갖는 부지가 요구된다. 최종 처분장부지의 안전성은 제반 요건에 부합되는 사실을 입증하는 부지적합성평가(site suitability assessment: 부지특성평가(site characterization)와 안전성평가(safety assessment)를 통해서 확보된다. 한편, 현 재 검토 및 의견수렴 단계에 있는 "일반기준고시(안)" [2]에 이 어서, 처분장부지 환경과 관련하여 규제차원에서 준비 예상되 는 규정들은 사용후핵연료의 처분과 관련하여 소위, "고준위 방사성폐기물처분장부지위치에관한기술기준”, 동 “부지특성 평가보고서작성지침” 및 “안전성평가보고서작성지침” 등이 다. 상용사업 측면에서는 당연히 이들 규정과 관련되는 업무 수행을 위해 종합수행계획과 관련 부문의 기술지침서 및 절차 서들이 준비되어야 할 것이다.

\section{나. 다중방벽 성능 영향 요소}

심지층처분장의 안전성확보를 위한 부지 요건을 구성하는 요소에 포함되어야 하는 부문은 전체적인 업무의 흐름으로 볼 때, 처분시설의 성능과 안전성 그리고 처분시스템 설계를 위 해 직 · 간접적으로 요구되는 지질환경 특성 관련 자료를 구성 하는 요소들이다(Figure. 2), 한편, 이들 요소들은 장기적 지질 안정성, 격리기능 및 지연기능 등 세 가지 분야와 관련되는 인 자로 구성된다. 원칙적으로 처분장부지 지질환경 요건(이하 지질환경 요건)이라 함은 건설허가 신청을 위한 부지특성평가 용 후보부지에 적용하여 최종 처분장의 처분안전성확보를 위

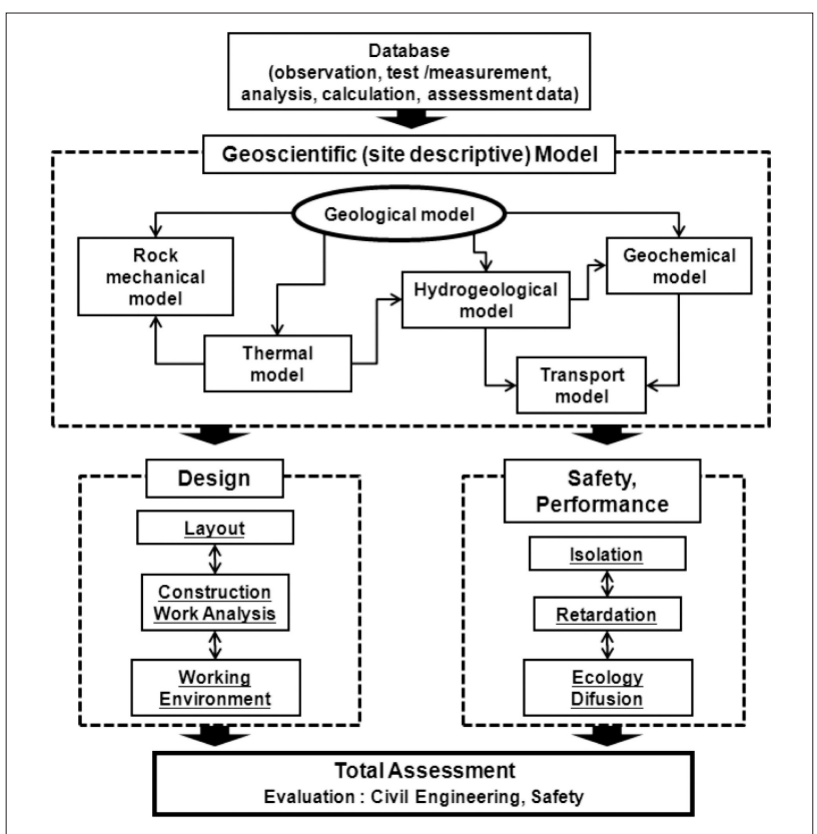

Fig. 2. Approach for the development of deep geological repository for SNF.

한 지질환경특성에 대한 요구조건으로 정의할 수 있다. 처분 지질환경 요건 관련 기술부문의 세부적 정의 내용은 후보부지 조사의 목적(선별평가, 선정, 특성평가 등)에 따라 단계적으로 적용 내용의 수준을 탄력적으로 변경 및/혹은 가중 적용할 수 있다.

\section{다. 처분장부지의 지질환경 요건에 관한 IAEA 권고}

국제적인 규정과 일반적으로 수용하고 있는 관례를 토대로 각 국가들은 자국내 타 법률과 제반 제도적 범주 내에서 방사 성폐기물의 관리를 위한 제도적 규제의 틀이 설정, 제시되어 야 한다. 이의 확립을 위해 IAEA에서 11 개 조항의 처분장 부 지요건을 제시하였다[23]. 이 중에서 폐기물운반, 토지이용 및 사회적영향 등을 제외한 7 개 항목은 지질환경에 관한 요건과 직·간접적으로 연관되는 내용이다.

\section{라. 지질환경 요건 체계}

심지층처분장부지의 지질환경 요건은 각 부문별로 현안 혹 은 의문 사항으로서 주로 처분시스템의 기능에 영향을 미치는 지질, 암석역학, 열적특성, 수리지질 및 지구화학 특성과 함께 핵종이동 관련 요소들로 구성된다. 현안사항 중 그 영향이 확 연하게 제기될 경우, 충분/선호 요건들이 어떠한 규모와 특성 을 가지고 영향을 미치게 되는지를 규명하게 된다. 이 현안은 후보부지조사 - 선정평가, 부지특성평가 업무 및 처분시스템 실증업무(URL 등) 수행과정에서 지질환경특성 인자들이 정량 
적으로 정의될 것이다. 일반적으로 처분안전성 기능은 다양하 고 수많은 인자들 간의 상호작용하는 조건에 좌우되며, 일부 기능은 다수 인자들의 조합으로 그 기능의 확보가 가능한 경 우도 있다. 처분부지의 지질환경 요건 확립을 위해 관련 용어 을 정의하여 적용하면:

- 처분기능(function): 심지층처분장의 성능 목표를 달성하 기 위하여 국제적 및 자국의 제반 법적 규정/지침을 만족하는 수준의 기능으로서 격리 및 지연기능 등으로 구분

- 충분요건(requirement): 처분장부지가 반드시 충족되어 야 하는 안전성 요구 조건으로 부지확보의 최종 목표이다. 처 분장의 안전성확보 기능이나 개별 인자와 연계되며, 절대적으 로 요구되는 수준을 목표치로 정의한다. 일반적으로 금지 혹 은 제한적인 방법으로 표시

- 선호요건(preference): 주로 부지선정평가 업무수행 단계 에 따라 유연하게 적용 가능한 요건으로서, 제시된 수준을 반 드시 만족하여야 할 필요는 없음

- 인자(parameter): 암석 · 암반의 상태, 정적현상, 동적 변 화현상 - 과정, 외형적 특성 등을 나타내는 물리, 화학적인 물 성이나 특성을 나타내는 성분, 수치 혹은 정성적인 내용으로 정의

- 지질환경 처분적합성지표(geoscientific suitability indicators): 처분장 부지선정이나 특성평가 등의 단계에서 충 분 및 선호 요건을 만족하는 정도를 나타내는 수치 혹은 범위 이다.

- 평가 기준/지침(criteria for evaluation): 부지의 처분적합 성을 정의한 규정 및 지침의 충족 정도를 판단할 수 있는 기준 값(values for suitability indicators)으로서, 이 지표를 토대로 부지확보 단계 별 적용 목적에 따라 탄력적으로 변경 사용 가 능하다.

심지층처분시스템의 다중방벽 성능에 영향을 미치는 지질
환경 요건을 정의하기 위한 기본적 구성 체계는 최상위로 국 제적 안전기본원칙과 함께 안전표준 관련 기술기준/지침을 만족하여야 한다. 이를 기반으로 국내의 관련 제도적 요건을 만족하여야 하며, 여기에는 기본요건과 함께 환경, 안전성 및 방사선방호 둥의 요건을 고려하여 접근한다. 그 아래 수준에 서 개발 도출된 심지층처분시스템의 격리, 지연기능과 함께 시설의 관리효율성 등을 고려한 요건으로 정의되어야 한다. 여기에는 크게 장기적 지질안정성과 수리지질환경으로 구성 되는 격리기능, 공학적방벽 및 천연방벽 성능 보호기능, 수동 적·능동적 핵종이동 지연기능, 그리고 건설·운영효율성으 로 표시되는 관리효율성 기능 등으로 분류 가능하다(Table 1). 이러한 수준의 요건들은 처분을 위한 지질환경의 기본적인 내 용으로서 대부분 정성적인 표현으로 서술되며, 처분장부지의 위치에 관한 기술기준의 내용이 여기에 해당된다.

\section{VI. 분야별 지질환경 기본요건 제안}

IAEA의 처분장 위치에 관한 기술지침과 그리고 사용후핵연 료 처분장 부지의 위치에 관한 기술 요건(안)(V항)을 등을 토 대로 사용후핵연료 처분장의 안전성확보를 위한 처분장 지질 환경 기본요건에 대하여 아래와 같이 15 개 충분요건 및 48 개 선호요건으로 구분하여 각각 아래와 같이 제안하였다:

\section{(1) 장기지질안정성}

- 충분요건-1: 처분장은 화산 등 지각변동으로 인하여 처분 시설의 안전운영에 영향을 미칠 것으로 예상되는 곳에 위치해 서는 아니된다.

- 선호요건-1: 처분장은 처분시설의 안전운영에 영향을 미 칠 것으로 예상되는 화산 등 지각변동지역으로부터 가능한 한 멀리 위치하여야 한다.

- 충분요건-2: 처분장은 지진 등 지각변동으로 인하여 처분

Table 1. A proposed structural frame on geoscientific indicators of site requirements and preferences for a deep geological repository.

\begin{tabular}{|c|c|c|c|c|c|c|c|c|}
\hline International & \multicolumn{8}{|c|}{ Safety Fundamental / Safety Requirements / Safety Guides } \\
\hline \begin{tabular}{c|} 
National \\
Requirements
\end{tabular} & \multicolumn{8}{|c|}{$\begin{array}{l}\text { (1)Basic/generic requirements (2)Environmental requirements (3)Safety requirements } \\
\text { (4)Radiation protection requirements }\end{array}$} \\
\hline \begin{tabular}{c|} 
Safety \& \\
Performance
\end{tabular} & \multicolumn{2}{|r|}{ Isolation } & \multicolumn{2}{|c|}{ Barrier protection } & \multicolumn{2}{|c|}{ Retardation } & \multicolumn{2}{|c|}{ Management } \\
\hline \begin{tabular}{c|c} 
System \\
Requirements
\end{tabular} & $\begin{array}{c}\text { Long-term } \\
\text { geological } \\
\text { stability }\end{array}$ & $\begin{array}{l}\text { Hydro-geological } \\
\text { condition }\end{array}$ & $\begin{array}{l}\text { Engineered } \\
\text { barrier }\end{array}$ & $\begin{array}{l}\text { Natural } \\
\text { barrier }\end{array}$ & Passive & Active & Development & $\begin{array}{l}\text { Operation \& } \\
\text { closure }\end{array}$ \\
\hline \begin{tabular}{c|c} 
Basic \\
Requirements \\
in each area
\end{tabular} & \multicolumn{8}{|c|}{$\begin{array}{l}\text { 〈Regulatory level: eg. Disposal Site Criteria > } \\
\text {-Licensee level: Qualitative requirements and preferences for all area }\end{array}$} \\
\hline $\begin{array}{l}\text { Safety } \\
\text { Function }\end{array}$ & \multicolumn{8}{|c|}{$\begin{array}{l}\text { (1) Canister integrity (2)Isolating capacity of buffer (3)Isolating and retarding capacity of rock } \\
\text { (4) Retarding capacity of rock (5)Influence on retardation in the geosphere (6)Biosphere-related matters } \\
\text { (7) Construction-related matters }\end{array}$} \\
\hline $\begin{array}{l}\text { Criteria, } \\
\text { guideline }\end{array}$ & \multicolumn{8}{|c|}{$\begin{array}{l}\text { 〈Technical criteria/guideline applying for site suitability/characterization, performance/safety assessment: } \\
\text { geoscientific suitability indicators }> \\
\text { - Quantitative criteria/guidelines of requirements and preferences should be produced by licensee } \\
\text { - Define through evaluation for long-term geological stability and deep geoenvironmental conditions of } \\
\text { preferred host rock around the country }\end{array}$} \\
\hline
\end{tabular}


시설의 안전운영에 영향을 미칠 것으로 예상되는 곳에 위치해 서는 아니된다.

- 선호요건-2: 처분장은 처분시설의 안전운영에 영향을 미 칠 것으로 예상되는 지진 등 지각변동지역으로부터 가능한 한 멀리 위치하여야 한다.

- 충분요건-3: 처분장은 활성단층 등 지각변동으로 인하여 처분시설의 안전운영에 영향을 미칠 것으로 예상되는 곳에 위 치해서는 아니된다.

- 선호요건-3: 처분장은 처분시설의 안전운영에 영향을 미 칠 것으로 예상되는 활성단층 등 지각변동지역으로부터 가능 한 한 멀리 위치하여야 한다.

- 충분요건-4: 처분장은 융기 · 침강 및 침식 등 지각변동의 영향으로 인하여 처분시설의 안전운영에 영향을 미칠 것으로 예상되는 곳에 위치해서는 아니된다.

- 선호요건-4: 처분장은 처분시설의 안전운영에 영향을 미 칠 것으로 예상되는 융기 - 침강 및 침식 등 지각변동지역으로 부터 가능한 한 멀리 위치하여야 한다.

- 충분요건-5: 처분장은 빙하작용과 같은 자연현상에 의한 지반의 응력변화로 인하여 처분시설의 안전운영에 영향을 미 칠 것으로 예상되는 곳에 위치해서는 아니 된다.

- 선호요건-5: 처분장은 처분장은 빙하작용과 같은 자연현 상에 의한 지반의 응력변화로 인하여 처분시설의 안전운영에 가능한 한 영향을 미치지 않은 곳에 위치하여야 한다.

- 충분요건-6: 처분장은 기후변화로 인한 해수면 변화로 처 분시설의 안전운영에 영향을 미칠 것으로 예상되는 곳에 위치 해서는 아니 된다.

- 선호요건-6: 처분장은 기후변화로 인한 해수면 변화로 처 분시설의 안전운영에 가능한 한 영향을 미치지 않는 곳에 위 치하여야 한다.

\section{(2) 지형}

- 선호요건-7: 처분장은 처분시설의 안전운영에 영향을 미 치지 않도록 지형 경사가 가능한 한 완만한 곳이어야 한다.

\section{(3) 지표수문}

- 선호요건-8: 처분장은 인접지역의 지표면에서 지하수로 충 전될 수 있는 표층수가 가능한 한 분포하지 아니하여야 한다.

- 선호요건-9: 처분장은 처분장과 가장 가까운 표층수와의 거리는 방사성핵종 방출에 의한 환경영향이 없을 만큼 가능한 한 충분히 먼 거리에 위치하여야 한다.

- 선호요건-10: 처분장은 홍수, 댐의 파손, 해수의 작용이나 기타 인위적인 사고로 인한 내수면의 범람시 처분시설의 안전 운영에 영향을 미치지 않을 것으로 예상되는 수위보다 상부에 위치하여야 한다.

\section{(4) 토질 및 암종}

- 선호요건-11: 처분장은 처분시설의 안전운영에 영향을 미 치지 않을 것으로 예상되는 가능한 한 토층의 두께가 가능한 한 얇고 표면배수가 용이한 특성을 갖는 곳이어야 한다.

- 선호요건-12: 처분장은 처분시설의 안전운영에 영향을 미 치지 않을 것으로 예상되는 가능한 한 충분한 두께를 가진 균 질한 모암이 분포하는 곳에 위치하여야 한다.

\section{(5) 지질구조 및 단열(대)}

- 충분요건-7: 처분장은 광역 소성전단대가 분포하는 곳에 위치해서는 아니 된다.

- 선호요건-13: 처분장은 광역 소성전단대로부터 가능한 한 먼 곳에 위치하여야 한다.

- 충분요건-8: 처분장은 기반암 혹은 지층에 균열이 많고 석 회암 혹은 탄전지역에 위치해서는 아니 된다.

- 선호요건-14: 처분장은 지층에 균열이 많고 석회암 및 탄 전지대로부터 가능한 한 먼 곳에 위치하여야 한다.

- 충분요건-9: 처분터널은 광역 주단열대가 통과하는 곳에 위치해서는 아니 된다.

- 선호요건-15: 처분터널은 핵종이동경로 역할을 할 것으로 예상되는 광역 주단열대로부터 가능한 한 먼 곳에 위치하여야 한다.

- 충분요건-10: 처분공은 국지 주단열대가 통과하는 곳에 위 치해서는 아니 된다.

- 선호요건-16: 처분공은 핵종이동경로 역할을 할 것으로 예 상되는 국지 주단열대로부터 가능한 한 먼 곳에 위치하여야 한다.

\section{(6) 암석역학}

- 선호요건-17: 처분장은 처분시설의 안전운영에 영향을 미 치지 않도록 구조적 및 역학적으로 안정된 기반암에 위치하여 야 한다.

- 선호요건-18: 처분장은 주변지역의 원위치 응력조건이 처 분장의 안전성에 영향을 미치지 않을 정도의 특성을 갖는 심 도에 위치하여야 한다. (천연방벽 보호기능 공동반영)

- 선호요건-19: 처분장은 건설로 인한 구조적, 역학적 및 수 리지질학적 특성이 처분시설의 안전운영에 영향을 미치지 않 아야 한다.

\section{(7) 열적특성}

- 선호요건-20: 처분장은 처분시설의 안전운영에 영향을 미 치지 않을 정도로 지온 및 열적특성이 안정된 기반암에 위치 하여야 한다.

- 선호요건-21: 처분장은 처분시설 운영으로 인한 열적 영향 의해 천부생태계에 영향을 미치지 않아야 한다 


\section{(8) 수리지질}

- 충분요건-11: 처분장은 처분시설의 안전운영에 영향을 미 치지 않을 것으로 예상되는 오래된 지하수가 분포하는 곳에 위치하여야 한다.

- 선호요건-22: 처분장 및 주변지역의 지하수압력은 다중방 벽의 안전성에 영향을 미치지 않을 정도로 충분히 낮은 조건 을 갖는 심도에 위치하여야 한다.

- 선호요건-23: 처분장 주변 지역의 지하수위는 단층작용, 해수작용 등의 자연현상에 의한 변동과 계절적인 변동이 처분 시설의 안전운영에 악영향을 미치지 않을 정도로 가능한 한 작아야 한다.

- 선호요건-24: 처분장 주변암반의 지하수 유동률, 유동경사 및 유속은 가능한 한 작아야 한다.

- 선호요건-25: 처분장 주위의 지하수 유동 체계내에서 방사 성핵종의 예상지연시간과 이동경로의 거리는 그 핵종이 충분 히 붕괴되어 인간생활권에 영향을 미치지 아니하도록 길어야 한다.

- 선호요건-26: 처분장 주위의 대수층은 지하수 유동체계상 가능한 한 다른 대수층과 연결되어 있지 아니하여야 한다.

- 선호요건-27: 처분장 및 주변지역은 처분안전성에 영향을 미치지 않을 정도의 개스 발생 억제조건을 갖는 적정 수리전 도도가 분포하는 곳에 위치하여야 한다.

- 선호요건-28: 처분장 및 주변암반의 투수량계수는 처분장 의 안전성에 영향을 미치지 않을 정도로 충분히 낮은 조건을 갖는 심도에 위치하여야 한다.

\section{(9) 지구화학 및 이송특성}

- 충분요건-12: 처분장은 공학적방벽의 성능에 영향을 미치 지 않도록 환원환경인 곳에 위치하여야 한다.

- 선호요건-29: 처분장은 주변 지하수 중 $\mathrm{pH}$ 성분이 처분시 설의 안전운영에 악영향을 미치지 않는 범위인 곳에 위치하여 야 한다.

- 선호요건-30: 처분장은 처분시설의 안전운영에 악영향을 미치지 않을 정도로 총 고체용해물의 농도가 낮은 환경조건 지역에 위치하여야 한다.

\section{(10) 핵종이동}

- 선호요건-31: 처분장 주위의 지하수 유동체계 내에서 방사 성핵종의 예상지연시간은 그 핵종이 충분히 붕괴되어 인간생 활권에 영향을 미치지 아니하도록 길어야 한다.

- 선호요건-32: 처분장은 가능한 한 방사성핵종에 대한 흡착 력이 있어야 하며, 특히 장반감기의 방사성핵종 이동을 지연 시키는 천연방벽이 발달한 곳이어야 한다.

- 선호요건-33: 처분장은 가능한 한 방사성핵종에 대한 확산
능력이 있는 천연방벽이 발달한 곳이어야 한다

\section{(111) 생태학적 특징}

- 충분요건-13: 처분장은 생태학적 특징과 관련하여 기타 관 련법으로 지정, 보호 되는 생태계 분포지역 또는 역사적, 학술 적으로 보존 가치가 있는 문화재가 존재하는 곳에 위치해서는 아니된다.

- 선호요건-34: 처분장은 관련법으로 지정, 보호되고 있는 생태계 보호지역으로부터 가능한 한 먼 거리에 위치하여야 한 다.

\section{(12) 천연자원보호}

- 충분요건-14: 처분장은 인간침투 등으로 처분시설의 안전 성에 영향을 미칠 것으로 예상되는 천연자원 분포지역에 위치 해서는 아니된다.

- 선호요건-35: 처분장은 처분안전성에 영향을 미치지 않을 정도로 충분한 방벽 두께의 유지 가능한 심도에 위치하여야 한다.

- 충분요건-15: 처분장은 토양, 산업광물 및 수자원보호지역 에 위치해서는 아니 된다.

- 선호요건-36: 처분장은 수자원보호지역으로부터 가능한 한 먼거리에 위치하여야 한다

- 선호요건-37: 처분장은 주변지역의 사회경제적 제반 여건 이 유리한 곳에 위치하여야 한다

\section{(13) 기상}

- 선호요건-38: 처분장은 강우 및 강설 등으로 인하여 가능 한 한 처분시설의 안전운영에 영향을 미치지 않는 곳이어야 한다.

- 선호요건-39: 처분장은 태풍, 돌풍, 지진해일, 폭풍해일 등 으로 인하여 가능한 한 처분시설의 안전운영에 영향을 미치지 않는 곳이어야 한다.

\section{(44) 건설, 운영 및 기타}

- 선호요건-40: 처분장은 처분장 및 주변지역의 자연방사선 배경치는 건설 및 운영 종사자의 보건에 영향을 미치지 않을 정도로 충분히 낮은 지역 혹은 낮은 상태를 유지할 수 있는 곳 에 위치하여야 한다.

- 선호요건-41: 처분장은 가능한 한 굴착작업 및 이에 관련 된 시추사실이 없는 지역에 위치하여야 한다. 다만, 그러한 사 실이 있을 경우에는 충분한 공간을 설정하여 처분장의 지형변 화 가능성을 최소화할 수 있는 곳이어야 한다.

- 선호요건-42: 처분장은 처분시설의 건설 및 운영 등 인위 적 및 자연적 원인에 기인하는 응력장의 변화로 안전성에 영 향을 미치지 않아야 한다.

- 선호요건-43: 처분장은 처분시설의 건설 등의 영향으로 지 
하수유동경로의 변화 혹은 투수성의 증가가 예상되지 않아야 한다.

- 선호요건-44: 처분장의 위치는 지표수 관리체계의 통합, 예상 밖의 방사성핵종 이동현상에 대한 대비, 방사성핵종의 이동현상을 측정할 수 있는 충분한 공간을 확보할 수 있는 곳 이어야 한다.

- 선호요건-45: 처분장은 가능한 한 토지이용의 효율성이 낮 은 지역에 위치하여야 하며 비행장이 있거나 고압전송 · 통신 선 및 가스와 석유수송로 등이 지나는 곳에 위치하여서는 아 니된다.

- 선호요건-46: 처분장은 폐기물을 안전하게 수송하는 데에 적합한 교통조건을 갖춘 지역이거나 교통시설의 건설이 용이 한 곳에 위치하여야 한다.

- 선호요건-47: 처분장은 군사활동으로 인하여 처분장 안전 운영에 영향을 미치는 지역이거나 그로 인한 방사성핵종 이동 의 증가가 예상되는 곳에 위치하여서는 아니된다.

- 선호요건-48: 처분장은 주변지역의 사회경제성 제반 여건 이 유리한 곳에 위치하여야 한다.

처분방벽의 성능을 확보 및 유지를 위한 처분장부지의 위치 에 관한 기술측면의 요건들 중에서 절대적인 충분요건은 이를 후보부지 비교 평가 과정에서 적용 목적에 따라 등급 부여 등 선호요건으로 변경하여 유연하게 사용할 수 있다. 이 요건들 은 공학적 및 천연방벽의 기능을 유지하는데 절대적으로 요구 되는 안정요소이다. 규제기관 및 사업자에 의해 추후 심도 있 는 검토과정을 통해서 항목의 추가 및 제외 등의 수정 - 보완 조치가 예상된다.

\section{VII. 심부지질환경 처분적합성지표 정의 방안}

전술한 국제적인 규제 권고 사항과 “일반기준고시(안)" 의 완성을 토대로, VI장의 제반 충분/선호 요건들은 국내 자국의 환경 여건과 타 규제 관련 조건을 만족하도록 규제 체계가 확 립되어 갈 것이다. 이와 관련하여 하위의 세부 기술지침들은 가능한 한 정량적인 수치 또는 범위의 형식으로 국내 지질환 경 처분적합성지표를 정의하게 될 것이다. 결국 처분사업 수 행 주체는 이 내용을 토대로 국내 환경조건을 반영한 자국 고 유의 처분시스템을 갖추게 될 것이다.

\section{가. 기본 방향}

개별 인자와 직접적으로 연관될 수 있는 값의 범위에 관한 충분요건은 명확히 정의되어야 한다. 일부, 안전기능을 정의
하는 충분요건과 관련한 값의 범위를 직접적으로 정의하는 것 은 가능하다 그러나 규제측면에서, 지질환경 인자를 정량화하 여 직접적으로 충분요건에 연관시키는 것은 매우 어려운 일이 다. 왜냐하면, 특정 인자는 처분성능을 결정하는 여러 가지 인 자들 중에서 한 가지일 뿐이며, 적정 값의 범위는 또 다른 인 자들의 값에 영향을 미치기 때문이다. 충분요건을 만족하지 못하는 경우 심지층처분장으로서 부적합한 것으로 판단하여 부지를 포기하거나, 처분장배치계획 등을 수정 - 보완하는 등 재검토 과정을 거쳐 목표를 달성하여야 한다. 충분요건을 만 족한다고 해서 반드시 안전기능이 충족된다는 것은 아니며, 수용 가능성 여부를 나타내는 것에 불과하다. 선호요건은 요 구되는 기능 확보를 위한 인자 값의 범위를 정의할 수도 있지 만, 수용 불가능한 기능을 위한 정확한 한계치를 정의하지 않 는 것이 바람직하다. 왜냐하면, 이러한 한계치는 수많은 미확 인 경우와 관련되거나 혹은 처분장 배치계획의 수정 등에 영 향을 미칠 수 있기 때문이다.

\section{나. 국외 및 국내 현황}

대부분의 처분사업에 관한 선진국의 경우 자국 고유의 충분 요건 및 선호요건을 설정하고, 이를 만족하기 위한 처분적합 성지표들을 정량적으로 정의 및 확립하여 상용사업에 적용하 고 있다. 또한 이에 앞서 자국의 대표적인 선호 암종을 대상으 로 단계적, 체계적으로 심부지질환경특성을 조사 및 평가하 고, 이를 토대로 연구용URL을 이용하여 최종적으로 정의하는 과정에 있거나 이미 거쳤다.

우리나라의 경우 대전유성지역 화강암분포지역에서 심부시 추공을 이용하여 일부 항목에 대하여 제한적으로 조사 및 평 가를 수행한 바 있다[24]. 하지만 이 결과는 우리나라의 대표 적인 처분적합성지표로 정의할 수는 없는 제한된 자료이다.

\section{다. 처분적합성지표의 정의 방안}

모든 부지선정 업무추진 혹은 이전 단계부터 충분 및 선호 요건에 해당하는 개별 부문에 대하여 요건을 만족할 수 있는 처분적합성지표를 나타내는 인자들이 정량화되고 정의되어야 할 것이다. 이들 적합성지표는 광역적 측면과 함께 지하심부 의 제반 환경특성을 파악하고 이를 처분적합성 측면에서 지속 적으로 수정 보완과정을 거치면서 평가함으로써 적정한 값이 나 범위로 정의 · 정립되어야 한다.

업무수행 효율성 측면에서, 국내 분포하는 모든 암종을 대 상으로 심부지질환경에 대한 적합성지표를 조사 및 평가하여 정의하기 보다, 다수 혹은 단일 선호 암종을 대상으로 단계적 및 체계적인 접근이 효율적이다. 지질환경 관련 인자는 직접 
적인 충분요건 혹은 주요 선호요건이 인자로서 정의되었거나, 하나 이상의 중요한 기능 분석 결과에 큰 영향을 미칠 것으로 예상되는 인자이다. 후보부지의 처분적합성에 대한 영향요소 측면에서 볼 때, 후보부지 선정평가, 후보부지조사 및 세부 부 지특성평가 단계에서 만족할 수 있거나 혹은 반드시 충족되어 야 할 지식수준이 논의 및 정립되어야 한다. 특정 인자를 유용 한 적합성지표로 수용과 특정 단계에서 기술지침으로 정의하 기 위해서는, 해당 인자의 추정 과정에서 그 정밀성을 평가할 수 있어야 한다. 업무추진 단계에 따라서 인자에 대한 지식은 증가하게 되지만, 단계 별로 그 중요성은 인자들 간에 상당한 변화가 불가피하다. 단순한 방법으로 예상되는 정밀성을 항상 정량화할 수는 없다. 한편 자국의 환경 여건을 반영한 이들 적 합성지표들은 처분장 건설허가 심사 등 규제측면에서 중요한 기술지침으로 활용하게 될 것이다.

\section{VIII. 토의 및 결언}

사용후핵연료 처분업무를 착수하기 전에 모든 관련 제반 규 정 및 기준이나 지침들은 사전에 준비 및 결정되어야 한다. 이 를 토대로 처분사업자 측면에서 확보 및 확립하여야 할 적용 기술 기준 및 지침들은 각 분야 및 추진 단계 별로 다양하게 요구된다. 이 중에서 가장 먼저 대두되는 업무는 처분장 후보 부지의 선정과 처분적합성평가(부지특성평가) 업무이다.

처분장 위치에 관한 국제적인 시각의 기술 기준과 해외 선 진국들의 사례 등을 토대로 우선적으로 준비하여야 할 제반 대책들이 단계적이고 체계적으로 구축되어야 한다. 사용후핵 연료 처분장의 안전성확보를 위한 처분장 지질환경의 기본적 인 요건에 대하여 정리하였다. 먼저 처분사업 측면에서 우리 나라의 사용후핵연료 처분장부지의 위치에 관한 기술적 요건 들을 검토하고, 이와 관련하여 처분장부지를 위한 기본요건 ( 15 개 충분요건과 48 개 선호요건)으로 구분, 정리하였다. 이 들 기본요건들은 우선 정성적인 표현으로 서술, 제시되어 있 으며, 향후 고시 예상되는 소위 “고준위방사성폐기물 처분장 부지의위치에관한기술기준" 내용과 동일한 수준의 특성을 갖 는다.

또한 이들 요건과 연계하여 처분사업자가 준비하여야 하는 정량적인 적합성지표들은 외국의 적용 사례들을 직접 반영할 수는 없기 때문에, 자국 고유의 처분시스템의 성능과 이에 영 향을 미치는 지질환경 특성의 정의에 대한 업무가 요구된다. 향후 이 부문에 대한 기술현황 분석을 통해서 규제측면과 사 업자 입장에서 상용 처분사업에 적용을 위한 각 부문별 특성 에 적합한 보다 정량적이고 구체적인 처분적합성지표에 관한
기술지침으로 확대 개발되어야 할 것이다. 이러한 과정은 연 구용URL 및 안전사례 작성 등을 이용한 우리 고유의 처분장 부지 지질환경 특성의 정의(type environment)와 상용처분장 후보부지 선별평가 과정 등을 통하여 다양한 분야의 의견수렴 을 거쳐서 최종적으로 제시될 것이다. 처분안전성 확보와 관 련한 요구조건, 규정, 기준 및 지침들은 자국내 타 법규와 함 께 인문사회 및 자연환경 관련 안전기준을 고려하여야 한다.

지질환경에 대한 조사 및 평가 행위와 결과가 결코 암석 · 암반과 지하수에 대한 정확하고 완벽한 지식 · 정보를 제공할 수 없기 때문에, 충분요건 · 선호요건과 기술 기준 · 지침 등의 적용은 사전에 자국의 자연환경 특성을 정확히 파악하고 이를 토대로 처분장부지의 적합성지표로 정의한 후 적용하여야 한 다. 모든 필수 불가결한 선호요건들을 만족한다면, 이러한 평 가는 처분장의 안전성을 만족하고 성공적인 건설업무 수행을 위해서 양호한 조건들을 확률론적으로 제시되어야 한다. 다만 일부 항목에 따라서 선진외국의 사례를 직접 적용할 수도 있 으나, 반드시 충분한 검토 및 의견수렴 과정을 거쳐 자국의 처 분관련 업무에 적용하도록 요구된다.

우리나라는 사용후핵연료 처분연구를 착수한지 십 수년 정 도 경과하였지만, 취득한 지식과 경험은 아직도 선진국 대열 에 미치지 못하고 있을 뿐만 아니라 사회적인 공감대 확보 역 시 미흡한 상태이다. 사용후핵연료 최종 처분장부지의 안전성 확보를 위해서 처분시스템의 다중방벽의 성능은 법적 및 윤리 적으로 요구하는 수준 이상의 기능이 보장되어야 한다. 이를 달성하기 위하여 처분장부지 지질환경 요건에 대한 정량 및 정성적인 적합성지표의 도출 업무를 필두로 후속되는 준비업 무에 이해와 인내를 가지고 단계적이고 체계적인 접근이 요구 된다.

\section{감사의 글}

본 연구는 2010년도 및 2011년도 지식경제부의 재원으로 한국에너지기술평가원(KETEP)의 지원을 받아 수행한 연구과 제입니다. (No. 201017102002D)

\section{References}

[1] Jae Hak Jeong, Kwan Hee Lee, Yun Keun Lee, Chan Woo Jeong and Byung Hwan Rho, "Technical Standards and Safety Review of the Low and IntermediateLevel Radioactive Waste Disposal acility", Journal of the Korean Radioactive Waste 
Society, vol.6(4), p357-368 (2008).

[2] KINS, "Generic Criteria for Deep Geological Disposal Facility of High Level Radioactive Waste(draft)"(2011), unpublished.

[3] International Atomic Energy Agency (IAEA), The Principles of Radioactive Waste Management, Safety Series No. 111-F, IAEA, Vienna (1995).

[4] International Commission on Radiological Protection (ICRP), Radiation Protection Principles for the Disposal of Solid Radioactive Waste, ICRP, Publication 46, Pergamon Press, Oxford and New York (1986).

[5] International Commission on Radiological Protection (ICRP), Annals of the ICRP, Publication 81, Radiation Protection Recommendations as Applied to the Disposal of Long-lived Solid Radioactive Waste, Elsevier (1998).

[6] International Commission on Radiological Protection (ICRP), The 2007 Recommendations of the International Commission on Radiological Protection ICRP Publication 103, Annals of the ICRP, Vol 37, Nos. 2-4 (2007).

[7] International Atomic Energy Agency (IAEA), Safety Principles and Technical Criteria for the Underground Disposal of High Level Radioactive Wastes, Safety Series No.99, IAEA, Vienna (1989).

[8] International Atomic Energy Agency (IAEA), Joint Convention on the Safety of Spent Fuel Management and on the Safety of Radioactive Waste Management, INFCIRC/546, IAEA, Vienna (1997).

[9] International Atomic Energy Agency (IAEA), Fundamental Safety Principles, Safety Fundamental, Safety Standard Series No. SF-1, Vienna (2006).

[10] International Atomic Energy Agency (IAEA), International Basic Safety Standards for Protection against Ionizing Radiation and for the Safety of Radiation Sources, Safety Series No. 115, IAEA, Vienna (1996).

[11] Nuclear Energy Agency (NEA), Joint CNRA/CRPPH/ RWMC Workshop, "Regulating the Long-term Safety of Radioactive Waste Disposal", Proceedings of an NEA International Workshop held in Cordoba, Spain, 20-23 January 1997, OECD, Paris (1997).

[12] Nuclear Energy Agency (NEA), Post-closure Safety Case for Geological Repositories, Nature and Purpose, NEA No. 3679, OECD, Paris (2004).

[13] Nuclear Energy Agency (NEA), Stepwise Approach to Decision Making for Long-term Radioactive Waste Management Issues and Guiding Principles, NEA No. 4429, OECD, Paris (2004).

[14] Nuclear Energy Agency (NEA), Progress Towards Geological Disposal of Radioactive Waste: Where Do We Stand?, Symposium Proceedings 23-25 January 2007, NEA No. 6319, OECD, Paris (2008).

[15] Nuclear Energy Agency (NEA), RWMC Regulator's Forum (RWMC-RF), Regulating the Long-term Safety of Geological Disposal of Radioactive Waste, Practical Issues and Challenges, Workshop Proceedings, NEA No. 6423, OECD, Paris (2008).

[16] Nuclear Energy Agency (NEA), A Collective statement by NEA Radioactive Waste Management Committee (RWMC), NEA No. 6433, OECD, Paris (2008).

[17] KAERI, "A Preliminary Study on the Suitability of Host Rocks for Deep Geological Disposal of High Level Radioactive Waste in $\operatorname{KOREA}(2000.2) "$, KAERI/TR-1521/2000 (2000)

[18] Ministry of Knowledge and Economy(MKE), "Establishment of the siting standard and procedure for a HLW repository", $\operatorname{KAERI}(2008$. 5), MKE, 1-2007-0-033 (2008).

[19] Environmental Protection Agency (EPA), 40 CFR Part 197, Public Health and Environmental Radiation Protection Standards for Yucca Mountain, NV; Final Rule (2001).

[20] Environmental Protection Agency (EPA), 40 CFR Part 197, Public Health and Environmental Radiation Protection Standards for Yucca Mountain, Nevada; Final Rule, October 152008 (2008).

[21] Sung Ho Lee, Yong Soo Hwang, “Technical Standards on the Safety Assessment of a HLW Repository in Other Countries", Journal of the Korean Radioactive Waste Society, vol.7(3), pp183- 
Study on Basic Requirements of Geoscientific Area for the Deep Geological Repository of ...

190 (2009).

[22] SKB, Deep repository for spent nuclear fuel. Main, Report (Volumes I and II), SR 97 Post-closure safety, Svensk Karnbranslehantering AB, Stockholm (1999).

[23] IAEA, 1977, Site Selection Factors for Repositories of Solid High-Level and Alpha-Bearing Wastes in Geological Formations, Technical Report Series No.177, International Atomic Energy Agency, Vienna.

[24] KAERI, Analysis of Overseas Status on the Geoenvironmental Requirements for Deep Geological Disposal of Spent Nuclear Fuel, KAERI/TR-4339/2011, 84pp (2011). 